Krzysztof Wojciech Baran

https://orcid.org/0000-0001-5165-8265

Jagiellonian University

\title{
LEGAL PROTECTION OF TRADE UNIONISTS AFTER THE AMENDMENT OF 5 JULY 2018 TO THE TRADE UNIONS ACT
}

\begin{abstract}
On 5 July 2018 the Polish Sejm adopted an amendment to the Trade Unions Act. It significantly changes the status of trade unionists at the company level. The starting point for further deliberations is that as from 1 January 2019 these entitlements will be granted not only to trade unionists employed on the basis of a contract of employment, but also to other persons engaged in gainful employment. By this I mean both those performing work on the basis of civil law contracts as well as self-employed. The July amendment to the Trade Unions Act regarding the legal status of trade unionists concerns their unpaid leaves, leaves from work duties and leaves to perform ad hoc activities and protection of sustainability of employment. These entitlements will be discussed in this Art. in such sequence.
\end{abstract}

Słowa kluczowe: związkowcy, prawo do bezpłatnego urlopu

Keywords: trade unionists, right to unpaid leave

ASCJ: 3308, JEL: K 31

The starting point for further deliberations will be the observation that the mechanisms adopted in the July amendment (Journal of Laws Dz.U. 2018, item 1608) refer to both the personal and the material level. For reasons of clarity, I will start the analysis with the former. The amended provisions of the Trade Unions Act are universal and refer to all categories of employers within the meaning of Art. $1^{1}$ (2) of the said Act. Therefore, they concern not only employers who employ employees, but also employers of nonemployees and heterogeneous employers (Baran 2018a, p. 7). Such standpoint is justified on the one hand by a cohaerentia argumentation, and on the other hand by the lege non distinguente directive. This does not mean, of course, that the scope of trade union rights in terms of leaves from work granted to the broad category of trade unionists is identical for all employers. This will be discussed further below.

The right to unpaid leave (Mrozowska 1997, p. 18; Książek 2016, p. 120) under Art. 25 (1) of the Trade Unions Act (Dz.U. 2019, item 263 consolidated text, as amended) 
is granted only to an employee appointed to perform an elected trade union function outside the place of work, if it involves an obligation to perform this function as an employee. On the contrary, it seems legitimate to claim that the right to unpaid leave is not granted to people who perform paid work on a basis other than an employment relationship (Baran 2018b, p. 72; Florek 2018, p. 55). The analyzed Art. 25 (1) is a special norm, therefore in the personal scope, according to exceptiones non sunt extendendae directive, it cannot be interpreted broadly. Similarly to the previous legislation, also in the July amendment the unpaid leave taken for the performance of out-of-work elected trade union function is obligatory. Therefore, the employer is obliged to grant it, if only statutory premises are met. It even seems permissible to bring a declaratory action under Art. 189 of the Code of Civil Procedure (Dz.U. 2018, item 1360 consolidated text, as amended, hereinafter referred to as: $\mathrm{CCP}$ ) in this matter.

The temporal dimension of the unpaid leave of a trade unionist has not been limited in the amended Trade Unions Act, which raises significant reservations. The mechanism of unpaid union leave for an indefinite period undoubtedly favours the formation of an oligarchy in industrial relations, creating a kind of caste of "professional" trade unionists detached from the work environment. The amendment does not however change the conditions to be met to obtain the right to unpaid leave (Książek 2016, p. 120).

The unpaid leave regulated by Art. 25 (1) of the Trade Unions Act may be granted to a trade unionist only at the request of a trade union organisation in whose structures the unionist is to perform the function. Its form, as in the current legislation, has not been clarified. So it can be submitted in any form. In my opinion a written form requirement should be introduced in the future. This is justified mainly by the considerations of legal certainty in labour relations. For the same reason, I believe that the procedure for granting the leave should be determined by statute, and not by the regulation of the Council of Ministers as is the case with the discussed amendment (Art. 25 (4)).

The new version of Art. 25 (2) of the Trade Unions Act, similarly to the previous regulations, provides for the right to a uniform and the right to use a dwelling or other accommodation, if the employer is entitled to determine the conditions of occupying such premises by employees. On the contrary, it seems legitimate to argue that this provision does not apply to other categories of unionists in paid employment. In the case of a violation of these rights, the employee is entitled to pursue his claims in court.

The July amendment has also introduced some changes as regards the leave from work duties under Art. 31 of the Trade Unions Act (Sierocka 2001, p. 27; Baran 2018b, p. 165). In personal terms, this right is granted to all categories of unionists engaged in gainful employment. They enjoy the rights and benefits relevant to the nature of work (Art. 31 (2)(1)), including the right to remuneration or cash benefit, provided that the management of a trade union organisation has submitted such a request. ${ }^{1}$

1 The employer retains the right to verify the content of the request. In particular, he can check whether the persons mentioned in it have an organisational function and whether the proposed number of days of the leave exceeds the statutory parameters. 
As I have already mentioned, in personal terms the leave from work duties under the amendment in question applies to all unionists engaged in gainful employment. Based on the lege non distinquente argument, it seems reasonable to claim that it applies to both employees and other persons providing paid work. ${ }^{2}$ As a result, the right to the "union leave" granted under the amendment to the Trade Unions Act, may be exercised also by persons employed under provisions of civil law (e.g. services contracts) and self-employed persons. Therefore, it introduces significant extensions of the personal scope, which in its consequences may disorganize work and generate additional financial and organisational burdens for employers.

In temporal terms, the leave stipulated in Art. 31 (1) of the Trade Unions Act may last for a maximum period of the term of office as a member of the board of the company trade union organisation. If, therefore, the term of office is shortened or even expires for other reasons, the trade unionist has no right to continue his leave from work. If the term of office has been extended, this entitlement will continue to apply. Also re-election to the management board for the next term entitles to leave from work.

In the event of refusal to grant the leave from work duties, a gainfully employed person may demand such leave before court (judgement of the Supreme Court of Poland of 6 May 1996, I PRN 37/96). However, such person cannot stop working, because this kind of arbitrary non-performance could result in legal sanctions. In the case of an employee, the employer could terminate employment without notice due to a serious violation of basic employee duties. As far as persons employed under civil law contracts are concerned, the provisions of contract law or subsidiary provisions of the Civil Code (Dz.U. 2018, item 1025 consolidated text, as amended, hereinafter referred to as: CC) may apply.

Pursuant to Art. 31 (2)(1) of the Trade Unions Act, a person in paid employment will ex lege enjoy, during the period of leave from work, all rights and benefits. Such standpoint can be justified by lege non distinguente argumentation. The only exception is the right to remuneration or cash benefit which is payable at the request of the trade union organisation. The July amendment to the Trade Unions Act unfortunately does not specify the rules for their payment. In particular in the case of persons engaged in gainful employment other than employees, this may generate serious problems in practice, due to the specificity of civil law employment, especially under unnamed contracts.

In personal terms, the discussed July amendment significantly extends leaves from work to include the time necessary to perform an ad hoc activity. Under Art. 25 (5) and (6) and Art. 31 (3) and (4), this entitlement is also vested in persons in gainful employment who are not employees. This means that it can be exercised not only by persons employed on a civil law basis, but also by self-employed persons and other trade unionists performing paid work. It applies to both those who perform functions in non-company and in company structures. The regulation adopted in Art. 25 (4) is different from the provisions stipulated in Art. 31 (6) of the draft law only in that the latter provision refers to the activity resulting from the trade union function outside the workplace.

${ }^{2}$ In the light of the textual wording of Art. 2 (7) of the Trade Unions Act, the rights specified in Art. 25 and 31 of the Act may be exercised also by officers who can unite in trade unions. 
The legislator has left unchanged the ad hoc characteristics of a Trade Unions Activity. Therefore, it is still of a subsidiary nature in the sense that union work should be done outside of vocational activity and thus outside of working time. The leave from work referred to is therefore not granted if the activity can be performed during non-working time.

On the basis of the analyzed amendment to the Trade Unions Act, similarly as under the previously applicable regulation, the ad hoc activities are not activities planned in advance on the basis of the work schedule of management boards, presidiums and company and inter-company committees of trade union organisations, as well as other permanent bodies (e.g. sections, teams, working groups). They are the everyday and normal way of conducting Trade Unions Activity. They should therefore be planned well in advance during the time off work. The duty of appropriate organisation of union work rests with its statutory bodies and particular unionists. What should be classified as an abuse of law, not benefiting from protection under Art. 8 of the Labour Code (Dz.U. 2018, item 917 consolidated text, as amended, hereinafter referred to as: LC), is planning of normal (routine) meetings of trade union bodies in the morning hours on business days. Only in the event of exceptional circumstances arising from the current operations of the employer (e.g. related to the employer's bankruptcy), it is justified to grant an employee a leave from work duties in order to attend the meeting of the permanent union body held in an extraordinary session. The trade union request for the leave should therefore refer to specific circumstances indicating the need to immediately perform ad hoc activities.

The July version of the Trade Unions Act in Art. 25 (5) in fine and Art. 31 (3) in fine provides that a person other than an employee who performs paid work (i.e. nonemployee) retains the right to remuneration for the time of the ad hoc activity. However, it does not specify a definition of the concept of remuneration, let alone the method of its calculation, which is a significant legislative shortcoming, the consequences of which may generate serious interpretational difficulties in practice, especially in civil law employment or self-employment. This gap can be supplemented by a regulation enacted under Art. 25 (4) and Art. $31\left(2^{1}\right)$ of the draft Trade Unions Act, which also does not seem to be the optimal solution in terms of the legislative technique.

Art. 25 (6) in fine and Art. 31 (4) in fine of the trade union law stipulates that for the period of performing ad hoc activities, the right to remuneration is retained unless the specific provisions provide otherwise. It is beyond discussion that such regulations may have a statutory or executive status (e.g. a regulation). Against the background of this regulation, a question arises whether such restrictions relating to remuneration can be set by provisions of collective agreements, other collective arrangements or by internal regulations. An answer to such question should be negative, since Art. $9 \$ 1 \mathrm{LC}$, which can be applied here in accordance with the systemic interpretation, clearly distinguishes between regulations and provisions. The interpretation option presented here is also strongly rooted in the a cohaerentia and a completudine argumentation.

It is also worth emphasizing that according to Art. 25 (8) of amendment to the Trade Unions Act, a collective agreement may specify the time limit for leave from work to be 
granted for the time necessary to perform the activity resulting from the union function of persons performing professional work. This norm is a classic example of multiplication of useless normative items. De lege lata there are no normative obstacles preventing the social partners from determining in a collective agreement or other collective arrangement of the time of leave from work necessary to perform a specific ad hoc activity, as well as other factors related to this type of leave (e.g. the issue of returning an employee to work after its exercise). This view is justified by the argument in dubio pro libertate with reference to Art. 59 (2) of the Constitution of the Republic of Poland.

Art. 25 (7) and Art. 31 (5) of the Trade Unions Act stipulate that a contract concluded between an employer and a non-employee person performing a paid work, which specifies the time for the performance of work, shall not be extended by the time of leave from work for the performance of ad hoc activities. This provision applies to all temporal agreements, both the diligent performance-based agreements and the resultbased agreements. In particular, in relation to the latter, it will require from a person performing paid work, other than an employee, precise planning of professional activities.

The amendment of 5 July 2018 to the Trade Unions Act also introduced significant changes as regards the protection of the employment relationship of trade unionists. In personal terms, the following categories of trade unionists were granted the guarantee of sustainability of the legal relationship:

- indicated members of the management board performing paid work (Art. 32 (1)(1)),

- other persons engaged in gainful employment who are members of a given trade union organisation, authorised to represent such an organisation in relations with the employer or with a body or a person acting on behalf of the employer in labour law matters (Art. 32 (1)(1)),

- three gainfully employed persons, indicated by the resolution of the founding committee (Art. 32 (7)),

- gainfully employed persons, performing an elected trade union function outside the company trade union organisation, who exercise their right to unpaid leave or leave from work duties.

De lege lata, protection is granted to unionists who have the status of a person in gainful employment. The definition of this concept is included in Art. 1 (1)(1) of the Trade Unions Act. In personal terms, on one hand it includes employees, and on the other, other persons who perform paid work on a basis other than the employment relationship, if they do not employ other people for this type of work, regardless of the basis of employment, if they have such rights and interests related to the performance of work that can be represented and defended by a (non-employee) trade union. As a result, the scope of protection has been significantly extended compared to the previously applicable regulations. It includes civil law employment, self-employment and administrative employment (e.g. police officers - Art. 2 (6) and (7) of the Trade Unions Act).

Art. 32 (7) of the Trade Unions Act establishes guarantees of protection of the employment relationship of unionists engaged in gainful employment indicated by 
the resolution of the founding committee of a trade union organisation. Functional considerations speak for the option that they should be members of the founding committee. In practice, they are directly exposed to harassment from the employer. If it is justified by specific circumstances, it is also acceptable to indicate other persons (e.g. persons who are founders of the trade union). Protection of sustainability of employment should result from the functions performed by them, related to the establishment of a new workplace organisation (judgement of the Supreme Court of 15 September 2011, II PK 54/11). Indication of a person not related to the activities of the newly formed trade union organisation should be classified as an abuse of right which is not subject to protection. In this situation, it is legitimate to apply the directive stipulated in Art. 8 LC.

When analyzing the status of unionists indicated by the founding committee, it is worth emphasizing that the statutory protection of employment applies regardless of whether they were subsequently elected to the board. Still valid is the view presented by the Supreme Court (judgment of 16 January 1996, I PRN 85/95) according to which in the period preceding the registration of a trade union, only members of the founding committee (de lege lata - persons designated by that committee) enjoy protection against termination of employment. Thus, it does not extend to the persons elected at that time to the management board.

According to the provisions of Art. 32 (9) of the Trade Unions Act, the mechanisms of protection of sustainability of employment apply also to people in gainful employment, who perform an elected trade union function outside the company's trade union organisation. This applies to all union levels, ranging from regional or industry, to nationwide. The statutory guarantee of stability of employment is only granted to those who exercise the right to unpaid leave or leave from work with the employer (judgment of the Supreme Court of 18 May 2007, I PK 275/06). In practice, this means that a person who is employed by several employers only enjoys protection from the employer who granted him the annual leave or leave from work duties. Therefore, the protection against change or termination of employment does not apply to people in an additional place of work. A similar rule applies to trade union members who have been appointed, otherwise than by election, to trade union advisory and consultative bodies.

In material terms, the guarantees of sustainability of a legal relationship (employment) of trade unionists laid down in Art. 32 of the Trade Unions Act refer to:

- unilateral termination of a legal relationship by notice (paragraph 1(1)) (judgment of the Supreme Court of 20 September 2005, II PK 21/05),

- mutual termination of a legal relationship (paragraph 1(1)) (alternatively: Niedbała 2010),

- unilateral change of wage or working conditions unfavourable to an employee (paragraph 1(2)). ${ }^{3}$

${ }^{3}$ According to a view presented by the Supreme Court in the judgment of 10 April 1997, I PKN $88 / 99$, a dismissal of a school principal is a unilateral change of wage or working conditions unfavourable to an employee within the meaning of Art. 32 of the Trade Unions Act. 
This is a numerus clausus list so it does not extend to situations which are not explicitly specified in this provision (exceptiones non sunt extendendae). This means that protection does not apply to trade unionists whose employment relationship has expired, ${ }^{4}$ both under statutory and contractual norms, whether due to the passage of time for which the contract was concluded or upon the date of completion of work. Also in the case of conclusion of an agreement to terminate the legal relationship, established either under labour law or under civil law (judgment of the Supreme Court of 7 June 1994, I PKN 29/94).

The mechanisms to protect the sustainability of employment of unionists (judgment of the Supreme Court of 17 May 2012, I PK 176/11) are relative in such sense that they only function if the trade union organisation does not consent ${ }^{5}$ to termination or transformation of the employment relationship (judgment of the Supreme Court of 23 January 2004, I PK 208/83). The consent or lack of consent to terminate or change a legal relationship with a trade unionist is a unilateral sovereign act. The deadline for submitting it under the provisions of the July amendment to the Trade Unions Act is:

1) 14 working days counted from the date of submission by the employer of a written notification of the intention to terminate or unilaterally change the legal relationship, stating the reason for the termination or unilateral change of the legal relationship,

2) 7 working days counted from the date of submission by the employer of a written notification of the intention to terminate the legal relationship without notice, stating the reason for termination of the legal relationship.

Art. 32 (1)(1) and (2) of the Trade Unions Act explicitly specifies that the time-limit to grant consent or to refuse to grant consent by the management of a trade union organisation starts as at the date of submission by the employer of a written notification of the intention to terminate or change the employment relationship. The textual wording of this provision supports the interpretation that the submission of the notification is sufficient for the deadlines to start running. However, based on the a completudine argumentation, I accept the application of mechanisms laid down in Art. 61 CC (in relation to employees, applied in connection with Art. $300 \mathrm{LC}$ ). As a result, it should be assumed that the notification is effectively served when it reached the company trade union organisation in such a manner that its management could become familiar with it. It does not matter, however, when a particular unionist became familiar with it (e.g. chairman of the board).

${ }^{4}$ In its judgment of 6 March 2008, II PK 192/07, the Supreme Court expressed an apt view that the protection provided for in Art. 32 (1) of the Trade Unions Act is not granted to an employee in the event of expiration of an employment relationship by virtue of law pursuant to Art. 95 (1)(3) of the Act of 12 September 1990 on Higher Education (Journal of Laws Dz.U. No. 65, item 385, as amended) and therefore Art. 57 \& 2 LC will not apply.

${ }^{5}$ According to the view presented by the Supreme Court in the judgment of 11 January 2006, I PK $106 / 95$, p. 62 , a trade unionist is protected because of the positions in two trade union organisations and the employer should obtain the consent to dismiss such unionist from both of these organisations. 
The Trade Unions Act explicitly provides for the written form of the notification of the intention to terminate or change the legal relationship with a trade unionist. Due to the fact that paragraphs $1^{1}(1)$ and (2) are specific norms, then a contrario it is legitimate to conclude that other forms of notification (e.g. oral) are ineffective, and as a result the time-limits provided for in the analyzed provision do not start running.

The abovementioned provisions require that the notification of the intention to terminate or change the legal relationship (employment) of a trade unionist should include reasons justifying it. They should be true, valid and specifically formulated. Repetition in it of the statutory formula (e.g. the employee has grossly violated his basic duties) should be considered defective, because it prevents the relevant trade union from presenting a substantive opinion. For example, the standards developed under Art. 30 $\$ 4 \mathrm{LC}$ may be applied to the notification of the intention to terminate or change the legal relationship.

Consent or refusal to grant consent by the trade union to terminate or change the legal relationship of trade unionists does not require justification. This does not mean, however, that it can be taken arbitrarily. The management of the trade union organisation or other authorized body should take into account all circumstances of the case, also the best interest of the employer. In particular, it cannot ignore the facts indicated by the employer in the notification. The decision in this matter taken without taking such facts into account is an abuse of law which does not enjoy protection. The normative instruments serving elimination of such practices are: either Art. 8 LC in relation to employees, or Art. 5 CC in relation to persons engaged in gainful employment on civil law grounds.

If no decision is taken within the deadlines specified in Art. $32\left(1^{1}\right)(1)$ and (2) of the Trade Unions Act, then in accordance with paragraph $1^{1}$ of this provision it is equivalent to granting consent by the management of the company's trade union organisation. In the normative sphere, we are dealing here with legal fiction, that is a norm that requires recognition of the occurrence of a certain legal fact, which in reality did not occur, i.e. granting consent. This mechanism limits the uncertainty in industrial relations, which is of significant importance in the context of extending the scope of the right of coalition to include a large number of non-employees. The regulation laid down in Art. 32 (12) of the Trade Unions Act refers to the classic formula of Cicero: cum quiescunt, probant which in the Justinian era took the form of a topic: qui tacuit, cum loqui debuit et potuit, consentire videtur (who was silent when he could and should speak, is considered to have consented).

Consent of the competent body of a trade union organisation must, by its very nature, be prior and thus must be expressed before the employer makes a declaration of intent. At this point, it is worth emphasizing that in the event that such consent was expressed, its revocation is subject to rigours provided for in Art. $61 \$ 1 \mathrm{CC}$ in fine in relation to employees in connection with Art. 300 LC.

Art. 32 (2) of the Act determines the duration of protection of the sustainability of legal relationship of trade unionists. As regards members of the management board 
and other employees authorized to represent the company's trade union organisation towards the employer, in accordance with the directive formulated in paragraph 2 of the discussed provision, it is vested for the period indicated in the resolution of the management board, and after its expiration - additionally for a period corresponding to half of the period indicated by the resolution, but not longer than one year after its expiration. Such regulation leaves to the management board of the company organisation a significant freedom in defining the period of protection without imposing any specific deadlines. Therefore, it may be of a long-term nature, because the Act does not directly associate it with the duration of the board mandate, or with the authority to represent the trade union organisation towards the employer. In this context, it seems that in the normative sphere the provisions of Art. $8 \mathrm{LC}$ are the only corrective mechanism in the case of an unjustified extension of the temporary scope of protection of a trade unionist. This provision states that one cannot exercise his right if it would be contrary to its socio-economic purpose or to the rules of social coexistence. Such action or omission is not considered to be exercising the right and does not benefit from the protection.

Art. 32 of the Trade Unions Act limits the number of trade unionists whose legal relationship (employment) is protected. Under paragraph 3 and 4 of this Article, two mechanisms for determining the number of protected trade unionists were introduced: parity (paragraph 3) and progressive (paragraph 4). Due to the fact that the law is silent on this matter, I believe that the choice of calculation method belongs to the board of the trade union organisation. This conclusion follows from the principle of union self-government based on the constitutional freedom of trade unions operating in the system of collective labour law. In this matter, therefore, the universal principle in dubio pro libertate should be applied.

In personal terms, the regulations laid down in Art. 32 (3) and (4) of the Trade Unions Act refer only to trade union organisations within the meaning of Art. $25^{3}$ (3) of the discussed Act. If none of the trade union organisations meets the criteria, then pursuant to Art. $25^{3}$ (2) of the Act, the representative trade union organisation is the organisation which unites the largest number of persons engaged in paid employment with the employer. This regulation is subsidiary in relation to the regulation of Art. $25^{3}(1)$ of the Trade Unions Act. This means that according to this provision the members of the organization can benefit from the protection granted by the guarantee of stability of employment only if there is no other representative trade union organisation. Otherwise, the mechanism laid down in Art. 32 (6) of the Trade Unions Act will apply. It provides that the protection stipulated in paragraph 1 of the discussed provision is granted to one indicated person in gainful employment, named in a resolution of the management of another company trade union organisation. This directive applies to trade union organisations that do not have the quality of representativeness within the meaning of Art. 32 (3) and (4) of the Act. In practice, this means that protection under Art. 32 (1) is granted only to one member of such a union, regardless of the number of its members.

Art. $32\left(9^{2}\right)$ of the Trade Unions Act stipulates that the management of the trade union organisation or the founding committee shall indicate in writing the trade unionists 
engaged in gainful employment, whose legal relationship (employment) is protected by indicating their first and last names and the period of protection. Written form limits the possibility of manipulating the scope of the protection. Against this background, a question arises whether an employer can control the temporal dimension of the protection. It seems that the principle of independence prevents such actions. On the other hand, there is nothing to prevent the courts from resolving disputes on the basis of specific cases of unionists. Changes in the indication are made by the management board or the founding committee of the trade union organisation within 7 days from the occurrence of the change. Only from the date of the notification of the employer the trade unionist is subject to protection of sustainability of the legal relationship.

Art. 32 does not comprehensively regulate the claims of persons performing paid work. It only specifies in paragraph $1^{3-4}$ the claims of unionists with a non-employee status. In relation to employees, the general principles provided for in the Labour Code will apply.

Art. $32\left(1^{3}\right)$ of the Trade Unions Act provides that if the employer breaches the conditions referred to in paragraph 1 , a person other than employee, who performs paid work, is entitled to compensation equal to six months' remuneration in the last period of employment, regardless of the amount of the loss suffered, and if the pay is not paid on a monthly basis - equal to 6 times the average monthly remuneration in the national economy, announced under the Act of 4 March 1994 on the Company Social Benefits Fund (Dz.U. 2018, item 1316 consolidated text, as amended). In addition, the person may seek damages or redress exceeding the amount of the compensation mentioned above.

The redress provided for in paragraph Art. $32\left(1^{3}\right)$ of the Trade Unions Act is not only compensatory, but also repressive, because it does not remain in direct correlation with the damage suffered as a result of termination or change of the legal relationship. As a result, the amount of the redress may exceed the amount of the damage. This kind of interpretation is expressly based on the textual wording of the Act ("regardless of the amount of the damage suffered").

Art. $32\left(1^{4}\right)$ of the Trade Unions Act specifies a mechanism for determining the amount of the remuneration. It takes into account the average monthly remuneration from the period of 6 months preceding the day of termination or unilateral change of the legal relationship. If, however, a person other than an employee performed paid work for less than 6 months - the basis for compensation is the average monthly remuneration from the entire period of the employment.

As regards the rules for determining the amount of compensation for violation of the terms of protection of a trade unionist who is not an employee, the general provisions of the Civil Code will apply. This also applies to mitigating the amount of compensation resulting from the factual or legal circumstances.

Similar mechanisms apply in the event of redress if the protected trade unionist suffered as a result of violation of the conditions provided for in Art. 32 (1) of the Trade Unions Act. It performs not only compensatory function, but also a preventive and educational function, because it should stop the employer from violating the rights of a protected non-employee trade unionist. In the case of employees, the claims 
model is based on Labour Code regulations. Thus, a trade unionist who has the status of an employee may, depending on the circumstances of the case, demand that the declaration of will to terminate the contract be rendered ineffective, and if the contract has been terminated, he may demand reinstatement (Stelina 2005, p. 30) or compensation. The employee shall decide on the choice of the claim, however the court may refuse to take it into account if it is impossible or pointless due to the circumstances (Art. $45 \$ 2$ LC).

Concluding the deliberations on the protection of sustainability of employment of trade unionists, consideration should be given to procedural and competence aspect. The starting point will be the statement that the claims of protected employees will undoubtedly belong to the jurisdiction of labour courts as matters regarding claims arising out of employment relationship or related to an employment relationship within the meaning of Art. $476 \$ 1$ (1) CCP. However, certain doubts arise as to disputes of persons in gainful employment, other than employees, as regards the entitlements stipulated in Art. 32 of the Trade Unions Act. There are two possible interpretation options: the first one - that these are civil law matters, and the second one - that these are matters arising from other legal relationships to which the provisions of labour law apply under separate provisions (Art. $476 \$ 1$ (2) CCP). Functional considerations speak for the second of the indicated interpretation options, because labour courts are better prepared to deal with union matters than civil courts.

To conclude the deliberations on the status of trade unionists in the amendment to the Trade Unions Act adopted on 5 July, it seems reasonable to claim that there will be a significant extension of rights in personal terms. Special rights were granted to large groups of trade unionists who are not employees, in particular self-employed workers and those providing work under civil law. This will produce a number of new problems for employers and additional financial costs. As a result, it can even disorganize labour relations. However, the concrete effects can only be assessed after a longer period of their functioning in industrial relations.

\section{References}

Baran K.W. (2018a) O pojęciu pracodawcy w zbiorowym prawie pracy - uwagi de lege lata $i$ de lege ferenda [The concept of employer in the collective labour law - de lege lata and de lege ferenda], "Monitor Prawa Pracy", nr 3, p. 7-10.

Baran K.W. (2018b) O zakresie prawa koalicji w zwiazkach zawodowych - uwagi de lege ferenda

[De lege ferenda remarks on the scope of the right of coalition in trade unions] [in:] G. Goździewicz (ed.), Umowa o pracę a umowa o zatrudnienie [Contract of service and contract for services], Warszawa.

Florek L. (2018) Zakres podmiotowy wolności koalicji [Personal scope of the freedom of coalition] [in:] J. Stelina, J. Szmit (eds.), Zbiorowe prawo zatrudnienia [Collective employment law], Warszawa. 
Książek D. (2016) [in:] K.W. Baran (ed.), Zbiorowe prawo pracy. Komentarz [Collective labour law. Commentary], Warszawa.

Mrozowska M (1997) Urlopy bezpłatne i zwolnienia od pracy związkowców [Unpaid leaves and other leaves from work of trade unionists], "Prawo Pracy", nr 1, p. 17-18.

Niedbała Z. (2010) Z problematyki szczególnej ochrony trwałości stosunku pracy [Special protection of sustainability of an employment relationship] [in:] A. Sobczyk (ed.), Ksiega pamiątkowa z okazji jubileuszu 40-lecia pracy naukowej Profesor Barbary Wagner [Memorial book for the $40^{\text {th }}$ anniversary of academic work of Professor Barbara Wagner], Warszawa.

Sierocka I. (2001) Zwolnienia od pracy i urlopy działaczy zwiazkowych [Leaves from work and holidays of trade unionists], "Praca i Zabezpieczenie Społeczne", nr 8.

Stelina J. (2005) Przywrócenie do pracy chronionego działacza związkowego w orzecznictwie Sadu Najwyższego [Reinstatement of a protected trade unionist in the case-law of the Supreme Court], "Praca i Zabezpieczenie Społeczne", nr 1.

\section{Court sentences}

Judgment of the Supreme Court of 7 June 1994, I PKN 29/94, OSNP 1994, no. 12, item 189. Judgment of the Supreme Court of 16 January 1996, I PRN 85/95, OSNP 1997, no. 1, item 9. Judgment of the Supreme Court of 6 May 1996, I PRN 37/96, OSNP 1997, no. 3, item 51. Judgment of the Supreme Court of 10 April 1997, I PKN 88/99, OSNP 1998, no. 1, item 10. Judgment of the Supreme Court of 23 January 2004, I PK 208/83, OSNP 2004, no. 23, item 401. Judgment of the Supreme Court of 20 September 2005, II PK 21/05, OSNP 2006, no. 15-16, item 231.

Judgment of the Supreme Court of 11 January 2006, I PK 106/95, MPP 2006, no. 2. Judgment of the Supreme Court of 18 May 2007, I PK 275/06, LEX no. 317825.

Judgment of the Supreme Court of 6 March 2008, II PK 192/07, OSNP 2009, no. 11-12, item 141. Judgment of the Supreme Court of 15 September 2011, II PK 54/11, LEX no. 1128326. Judgment of the Supreme Court of 17 May 2012, I PK 176/11, LEX no. 1148380. 